\title{
Predicting two components of career maturity in school based adolescents
}

Peter A. Creed PhD

School of Applied Psychology

Griffith University - Gold Coast

PMB 50 Gold Coast Mail Centre

Queensland Australia 9726
Wendy Patton PhD

School of Learning and Development

Queensland University of Technology

Kelvin Grove Campus

Queensland Australia 4059

Address for correspondence: Assoc Professor Peter Creed School of Applied Psychology

Griffith University- Gold Coast

PMB 50 Gold Coast Mail Centre

Queensland Australia

p.creed@mailbox.gu.edu.au 


\title{
Predicting two components of career maturity in school based adolescents
}

\begin{abstract}
Three hundred and sixty-seven secondary school students across five year levels (8-12) were assessed for levels of career maturity (attitude and knowledge), work commitment, work value, career decidedness (indecision and certainty), career decision-making self-efficacy and self-esteem, and indicated their age, gender, socioeconomic status, school achievement and work experience. Using two multiple regression analyses, the predictor variables were able to account for $52 \%$ of the variance of career maturity attitude, and account for $41 \%$ of the variance of career maturity knowledge. Self-efficacy, age, career decidedness (certainty) and work commitment were the main predictors of career maturity attitude. Age, gender, career decidedness (certainty), work commitment and career decidedness (indecision) were the main predictors of career maturity knowledge. Results demonstrated the importance of examining two aspects of career maturity (attitude and knowledge), and were discussed in the context of Super's $(1957,1990)$ theory of career development.
\end{abstract}

Key words: career maturity, career decidedness, career decision-making self-efficacy, work salience, work experience 
The career development theory of Super $(1957,1990)$, and its underpinning construct of career maturity that provides a viable base for understanding the transition from school to work, is receiving renewed empirical attention (Patton \& Lokan, 2001). Further, the applicability of the career maturity construct in countries other than the country of development continues to be the subject of research (Naidoo, Bowman, \& Gerstein, 1998; Stead \& Watson, 1998). Career maturity refers to the individual's readiness to make informed, age-appropriate career decisions and cope with career development tasks (Savickas, 1999). However, very little work has examined the construct in high school samples (Powell \& Luzzo, 1998), and even less has looked at adolescents in Australia, where only two studies have reported career maturity data (Lokan, 1984; Patton \& Creed, 2001).

In the present study, we explore aspects of career maturity with a group of Australian high school students. The study extends the work of Naidoo et al. (1998) who identified and tested predictors of career maturity (age, gender, socioeconomic status, education, racial/ethnic differences, locus of control, and work salience) in a sample of African-American university students. These authors tested a model that accounted for only nine percent of the variance in career maturity, with work salience having the most influential effect. They concluded, "other latent and observable factors that lie outside the domain of the current model must be included to provide a more comprehensive conceptualization" (p. 24).

The present study identifies a number of other correlates of career maturity (decidedness and indecision, decision making self-efficacy, school achievement, work experience and selfesteem) and tests them as predictors along with the variables included in the Naidoo et al. (1998) study (gender, SES, age, work salience, but not locus of control as it was not shown to be a strong predictor). The present study also examines two aspects of career maturity, namely attitudinal and knowledge components, which have long been integral components of the construct (Crites, 1978; Crites \& Savickas, 1995). 


\section{Correlates of Career Maturity}

A number of correlates of career maturity have received recurring attention. We do not review this literature in depth, but rather focus on the salient conclusions from this research (for recent reviews see Patton \& Lokan, 2000; Prideaux \& Creed, 2001). For age, crosssectional studies typically report older students scoring higher on career maturity measures than younger students. This has been found for students in Israel (Fouad, 1988), Australia (Patton \& Creed, 2001), Canada (Alvi \& Khan, 1983), South Africa (Watson \& Van Aarde, 1986) and Nigeria (Achebe, 1982). However, not all studies report this relationship. Powell and Luzzo (1998), for example, found no association with a group of US high school students.

For gender, the majority of studies has found that females have higher scores on career maturity measures than males (Fouad, 1988; Luzzo, 1995; Rojewski, Wicklein, \& Schell, 1995). In some countries, for example in South Africa (Watson, 1984) and Nigeria (Achebe, 1982), males have been found to score higher than females, while other studies have failed to find any differences (Kelly \& Colangelo, 1990; Watson, Stead \& De Jager, 1995). In relation to socioeconomic status, small correlations have been found with career maturity in school age adolescents (Crites, 1978; Super \& Nevill, 1984) and in university students (Nevill \& Super, 1988). Where significant relationships have been found, they have usually been with the knowledge rather than the attitudinal measure of career maturity.

Only a few studies have examined career maturity and work salience. Naidoo et al. (1998) reported work salience as the most important predictor of career maturity, while strong positive correlations have been found with orientation to work (Sheridan, 1981), work role salience (Lokan \& Shears, 1995) and work commitment (Creed \& Patton, in press). For actual work experience, mixed results have been reported. Creed and Patton (2001) found higher career maturity scores for high school students with work experience, while Niles and 
Herr (1989) found no differences between their two groups. A small body of research has established a link between career maturity and school achievement. Tan (1989) found differences between low achievers and high achievers on career maturity. More recently, Luzzo (1993) reported a significant relationship between self-reported GPA and career decision-making skills. For career indecision, several studies have reported higher levels of career maturity for university (Brusoki, Golin, Gallagher, \& Moore, 1993; Hartman, Fuqua, \& Hartman, 1983) and high school students (Rojewski, 1994) who were more decided. Similar results have been reported for career decision-making self-efficacy (Betz, Klein, \& Taylor, 1996b; Luzzo, 1993) and self-esteem (Bloor \& Black, 1993).

\section{The Present Study}

The present study seeks to expand earlier work that identified career development variables as predictive of career maturity. The brief review above has identified a number of correlates of career maturity over and above those identified by Naidoo et al. (1998). Based on this research and the theoretical propositions of Super $(1957,1999)$, it is expected that there will be a relationship among these variables and the variable of career maturity. Career maturity in the present study will be operationalised as two component parts, namely career maturity attitude and career maturity knowledge. It is expected that a different combination of the career development variables will be associated with these two component parts of career maturity. Lastly, following the work of Naidoo et al., it is expected that age and work salience will be the most significant predictors of career maturity. Because of the important role already identified for work salience in predicting career maturity, this variable will be examined from two perspectives, namely work commitment and work value. 


\section{Method}

\section{Participants}

Participants were 367 high school students enrolled in Grades 8-12 in one school in southeastern Australia. There were 200 (54\%) females and 167 (45\%) males, who ranged in age from 12.73-18.42 years $(M=15.49, S D=1.47)$. Of these, $255(69 \%)$ reported having participated in paid work external to the school. Three levels of socioeconomic status (SES) were calculated based on parental education (Anderson \& Vervoorn, 1983, p.172). There were $110(30 \%)$ students with parents having up to 10 years of education, $138(38 \%)$ with parents completing 12 years of education, and $119(32 \%)$ with parents with tertiary education. There were no ethnic groupings of significant size in the school, which is typical of schools in Australia. Students were also asked to self-report their most common level of achievement across all subjects. The six categories were based on those used by the state education authority and included -SA, SA, SA-HA, HA, HA-VHA and VHA (where SA = Satisfactory, HA = High Achievement and VHA = Very High Achievement). Four percent of students indicated they typically achieved below a Satisfactory level, 13\% typically achieved SA, 23\% achieved between SA-HA, 36\% achieved HA, 18\% achieved between HA-VHA, and seven percent achieved VHA.

\section{Measures}

Career Maturity. The 72-item Australian version of the Career Development Inventory (CDI-A; Lokan, 1984) measures two broad aspects of career maturity, namely Career Development Attitude (CDA; 28 items) and Career Development Knowledge (CDK; 44 items). CDA (e.g., "How much time and thought have you given to choosing a career in general) taps aspects of career planning and career exploration. CDK (e.g., "Exploring interests, abilities, and opportunities is something which people should be encouraged to engage in: throughout their lives/when they become dissatisfied with the way things 
are/when they lose their jobs/when things start to go wrong") taps knowledge of the world of work and decision-making skills. The response format changes within the subscales depending on the types of questions asked, but in each case higher scores indicate higher levels of career maturity. Lokan reported validity evidence for the CDI-A based on appropriate age differences in scores and factor analysis, and indicated adequate internal reliability. Internal reliability coefficients in the present study were .90 (CDA) and .85 $(\mathrm{CDK})$.

Career Decision-Making. The 19-item Career Decision Scale (CDS; Osipow, 1987) consists of two subscales, the 16-item CDS-Indecision scale (CDS-I) that provides a measure of career indecision, and the 2-item CDS-Certainty scale (CDS-C) that indicates the degree of certainty that the respondent feels in having made a career decision. There is one openended question that allows respondents to put their concerns in their own words, which is not reported in this study. Participants respond to items by indicating on a 4-point scale whether the item is "not at all like me" through to "exactly like me". Higher scores indicate greater indecision and more uncertainty, respectively. Internal reliability coefficients have been reported in the .80 range (Hartman et al., 1983). For the present study they were .86 for the CDS-I and .71 for the CDS-C. Concurrent (Hartman \& Hartman, 1982), construct (Hartman et al., 1983) and predictive validity (Hartman, Fuqua, Blum \& Hartman, 1985) have all been adequately demonstrated.

Work Salience. Two aspects of work salience were measured. Firstly, an 8-item Work Commitment scale (WC; Rowley \& Feather, 1987) was used to measure the importance of entering the workforce. The original scale was adapted by converting the wording from present to future tense to make it suitable for use with students. For example, "I get bored without a job" was amended to "I would get bored without a job." Students rated their level of agreement on a 5-point scale with end-points of "disagree a lot" and "agree a lot". Higher 
scores represent a stronger commitment to being in the workforce. Rowley and Feather reported an internal reliability for the scale of .85 . In the present study this was .80 . Secondly, a 3-item scale (Feather \& Davenport, 1981) was used to measure the perceived value of work (WV). A sample item was “Does most of the satisfaction in a person's life come from their work?". Students rated their level of agreement on a 7-point scale, with endpoints of "definitely not" to "yes, definitely." Higher scores represented stronger WV. Feather and O'Brien (1986) reported an internal reliability coefficient of .59 with an unemployed youth sample. In the present study this was .70.

Career Decision-making Self-efficacy. The 25-item short version of the Career Decisionmaking Self-efficacy scale (CDMSE; Betz, Klein, \& Taylor, 1996a) measures confidence regarding ability to make career-oriented decisions. A sample item is, "How confident are you that you could determine what your ideal job would be?". Participants rated their level of confidence on a 5-point scale, with end-points of "no confidence at all" to "complete confidence". Higher scores indicate more career-related confidence. Betz et al. (1996b) reported adequate validity for the scale, and indicated satisfactory internal reliabilities ranging from .73 to .83 . The internal reliability for the present study was .93 .

Self-esteem. The 10-item Rosenberg Self-esteem Scale (SE; Rosenberg, 1965) measures global self-worth. Students rated how strongly they agreed with each item (e.g., "I feel that I have a number of good qualities"), on a 4-point scale using anchors of "strongly agree" to "strongly disagree", with higher scores indicating higher self-esteem. The SE has been used widely in studies with young people (Winefield, Tiggemann, Winefield, \& Goldney, 1993). The internal reliability coefficient for the present study was .83 .

Work experience. To gain a measure of work experience, students were asked to indicate if they were working now or had worked in the past in any paid part-time/casual job external 
to the school. Students who reported any such employment were deemed to have met the criterion for work experience.

\section{Procedure}

The data reported here constitute one aspect of a larger study examining the correlates of career maturity for high school age students (Patton \& Creed, 2001). Classroom teachers who had been provided with instructions regarding the administration protocol administered the survey forms to students, who completed it in class time.

\section{Results}

\section{Summary Statistics}

Summary data and bivariate correlations among dependent and independent variables are reported in Table 1. For the dependent variables, Career Development Attitude (CDA) was significantly and meaningfully ( $\geq .33$; Tabachnik \& Fidell, 1996) associated with age, Career Decision-making Certainty (CDS-C) and Career Decision-making Self-efficacy (CDMSE), such that those with higher levels of career planning and exploration were older, were more career certain and had higher levels of career confidence. Career Development Knowledge (CDK) was positively associated with Work Commitment (WC) and Career Decision-making Indecision (CDS-I), and negatively associated with gender, such that those with more world of work knowledge and better career decision-making were more likely to be female, to have stronger work commitment and to be more career undecided. WC was further associated with Work Value (WV), such that students with a stronger commitment to work also valued work more highly. CDS-I was further associated with CDMSE, such that students with more indecision were less confident about making career-related decisions. Similarly, for CDS-C, students with less certainty were less confident about making career-related decisions. CDMSE was positively associated with Self-esteem (SE), indicating that students confident about making career-related decisions reported higher levels of esteem. Age was further 
associated with Work Experience (WE), such that the older the student the more likely he or she was to have engaged in paid employment. No meaningful associations were identified for Socio-economic Status (SES) or School Achievement (SA). The results generally support the proposition that career maturity is associated with a wide range of variables, and that a different combination of variables are associated with Career Development Attitude and Career Development Knowledge.

\section{Predicting Career Maturity}

Two multiple regression analyses were conducted to test the hypotheses in relation to predicting Career Development Attitude (CDA) and Career Development Knowledge (CDK). In the first analysis, CDA was entered as the dependent variable, and CDK, age, gender, SES, SA, WE, WC, WV, CDS-I, CDS-C, CDMSE, and SE were entered as the independent variables. Summary data are presented in Table 2. In the second analysis, CDK was entered as the dependent variable, and CDA along with the other variables in from the first analysis were entered as the independent variables. Summary data are presented in Table 3. Note, dummy variables were created for gender (base level $=$ female), SES (base level $=$ 10 years of education) and WE (base level = paid work experience).

For CDA, the results indicated a significant model fit, $F(13,353)=29.52, p<.001$, and that the independent variables included in the model were able to account for $52 \%$ of the variance $\left(R^{2}=.52\right)$. Examination of the standardized beta weights $(\beta)$ indicated that the strongest predictor was CDMSE, followed by age, CDS-C and WC, all of which produced significant individual predictions over and above the group prediction. 
Table 1

Means, Standard Deviations and Pearson Product-Moment correlations for dependent, independent and demographic variables. $N=$ 367

\begin{tabular}{|c|c|c|c|c|c|c|c|c|c|c|c|c|c|c|}
\hline Variable & $\underline{\mathrm{M}}$ & $\underline{\mathrm{SD}}$ & 2 & 3 & 4 & 5 & 6 & 7 & 8 & 9 & 10 & 11 & 12 & 13 \\
\hline 1. $\mathrm{CDA}$ & 100.72 & 18.19 & $.32 * * *$ & $.32 * * *$ & $.27 * * *$ & $.32 * * *$ & $.46 * * *$ & $.56 * * *$ & $.22 * * *$ & $.39 * * *$ & $.16^{* *}$ & -.08 & .10 & $-.24 * * *$ \\
\hline 2. $\mathrm{CDK}$ & 23.56 & 6.19 & - & $.34 * * *$ & $.21 * * *$ & $.34 * * *$ & -.03 & $.28 * * *$ & $.20 * * *$ & $.30 * * *$ & $.23 * * *$ & $-.38 * * *$ & .08 & $-.13 *$ \\
\hline 3. WC & 31.63 & 5.88 & & - & $.41 * * *$ & $.28 * * *$ & .07 & $.30 * * *$ & $.17 * *$ & -.06 & $.19 * * *$ & $-.22 * * *$ & .04 & -.06 \\
\hline 4. WV & 15.08 & 3.13 & & & - & $.20 * * *$ & .09 & $.27 * * *$ & $.13 *$ & .05 & -.03 & -.05 & -.02 & -.03 \\
\hline 5. CDS-I & 48.10 & 8.58 & & & & - & $.17 * *$ & $.41 * * *$ & $.27 * * *$ & .08 & $.14 * *$ & $-.19 * * *$ & .03 & .00 \\
\hline 6. CDS-C & 5.15 & 1.59 & & & & & - & $.40 * * *$ & $.21 * * *$ & $.18 * *$ & $.19 * * *$ & .07 & -.05 & -.08 \\
\hline 7. CDMSE & 86.91 & 16.10 & & & & & & - & $.41 * * *$ & $.13 *$ & $.23 * * *$ & -.08 & .07 & -.09 \\
\hline 8. SE & 30.32 & 4.78 & & & & & & & - & -.05 & $.23 * * *$ & .05 & -.02 & -.00 \\
\hline 9. Age & 15.59 & 1.47 & & & & & & & & - & -.08 & -.06 & .02 & $-.48 * * *$ \\
\hline 10. SA & 6.72 & 1.21 & & & & & & & & & - & $-.23 * * *$ & .09 & .03 \\
\hline 11. Gender & & & & & & & & & & & & - & -.06 & -.04 \\
\hline 12. SES & & & & & & & & & & & & & - & .04 \\
\hline 13. WE & & & & & & & & & & & & & & - \\
\hline
\end{tabular}

Note. CDA = Career Development Attitude subscale of the Career Development Inventory - Australia; CDK = Career Development Knowledge subscale of the Career Development Inventory - Australia; WC = Work Commitment scale; WV = Work Value scale; CDS-I = Indecision subscale of the Career Decisionmaking scale; CDS-C = Certainty subscale of the Career Decision-making Scale; CDMSE = Career Decision-making Self-efficacy scale; SE = Self-esteem scale; $\mathrm{SA}=$ School Achievement; SES = Socio-economic Status; WE $=$ Work Experience. $*=p<.05, * *=p<.01, * * *=p<.001$ 
Table 2

Summary of Multiple Regression Analysis for Variables Predicting Career Development Attitude (CDA); $N=367$

\begin{tabular}{lrcc}
\hline & $B$ & $S E B$ & $\beta$ \\
Variable & & & \\
\hline & -0.20 & 0.14 & 0.07 \\
CDK & 3.30 & 0.58 & $0.27 * *$ \\
Age & 1.03 & 1.53 & 0.03 \\
Gender & 2.25 & 1.66 & 0.06 \\
SES & 3.65 & 1.72 & $0.09 *$ \\
SES & 0.25 & 0.62 & 0.02 \\
SA & -1.73 & 1.70 & -0.04 \\
WE & 0.51 & 0.14 & $0.17 * * *$ \\
WC & 0.34 & 0.24 & 0.06 \\
WV & 0.11 & 0.09 & 0.05 \\
CDS-I & 2.94 & 0.49 & $0.26 * * *$ \\
CDS-C & 0.36 & 0.05 & $0.32 * * *$ \\
CDMSE & -0.07 & 0.16 & -0.02 \\
SE & & & \\
\hline Note. ${ }^{*}=p<.05, * * *=p<.001$. & &
\end{tabular}

For CDK, the results also indicated a significant model fit, $F(13,353)=18.47, p<.001$, with the independent variables in the model accounting for $41 \%$ of the variance $\left(R^{2}=.41\right)$. Examination of the standardized beta weights indicated that the strongest predictor was age, followed by gender and CDS-C, all of which produced significant individual predictions over and above the group prediction. 
Table 3

Summary of Multiple Regression Analysis for Variables Predicting Career Development Knowledge (CDA); $N=367$

\begin{tabular}{lccc}
\hline & $B$ & $S E B$ & $\beta$ \\
Variable & & & \\
& & & \\
CDA & 0.03 & 0.02 & 0.08 \\
Age & 1.32 & 0.22 & $0.31^{* * *}$ \\
Gender & -2.94 & 0.56 & $-0.24^{* * *}$ \\
SES & 0.17 & 0.63 & 0.01 \\
SES & 0.29 & 0.66 & 0.02 \\
SA & 0.69 & 0.23 & $0.14^{* *}$ \\
WE & 0.40 & 0.64 & 0.03 \\
WC & 0.17 & 0.05 & $0.16^{* *}$ \\
WV & 0.11 & 0.09 & 0.06 \\
CDS-I & 0.11 & 0.03 & $0.15^{* *}$ \\
CDS-C & -0.88 & 0.19 & $-0.23^{* * *}$ \\
CDMSE & 0.03 & 0.02 & 0.07 \\
SE & 0.16 & 0.06 & $0.12^{* *}$ \\
& & & \\
Note. ${ }^{* *} p<.01 . * * * p<.001$. & &
\end{tabular}

\section{Discussion}

The two regression analyses conducted in the study explained substantial proportions of the variance, first in career development attitude (CDA), and second in career development knowledge (CDK). As hypothesized, different combinations of variables were determinants of CDA and CDK, although there were only minor differences (gender and work commitment). For attitude (CDA), the analysis indicated a significant model fit that accounted for 52 percent of the variance. The strongest predictors in this sample of students were career decision-making confidence, age, how decided and comfortable he or she was in having settled on a career path, and work commitment. Clearly, older students were more likely to engage in career exploration and planning, but it was also the career related variable of confidence, being less comfortable with one's chosen career path, and being committed to being in the work force that were important in understanding these behaviors. These data support the hypothesis in relation to age, 
and are in keeping with the theoretical notion of a developmental progression in career maturity (Super, 1957, 1990). Importantly, and contrary to the hypothesis cited, while work commitment did account for a significant proportion of the variance in maturity attitude, this predictor was not the most powerful effect, which was found by Naidoo et al. (1998) using their related variable of role salience. This may be explained partly by the different measures used in each study, and partly by the shared variance of work commitment being accounted for when other variables are included in the model, but it also does indicate that other cognitive variables (in this case efficacy and decidedness) may play more crucial roles. Work value, the other work salience measure used in the present study, did not play a significant role in predicting CDA.

For career development knowledge $(\mathrm{CDK})$, the regression analysis accounted for 41 percent of the variance, which is less than that explained for attitude (CDA) using very similar predictor variables. Thus, from this study we can be more confident about the variables that predict career exploration and planning (CDA), than we can be about the variables that predict CDK (world of work knowledge and career decision-making know-how). The strongest predictor of world of work knowledge and career decision-making was age, which again supports the developmental explanation (Super, 1957, 1990) for these career maturity constructs. Gender was also an important predictor, which is further evidence that young women are better informed in relation to career related knowledge (Patton \& Creed, 2001). For CDK, being comfortable with one's chosen career path was associated with higher work knowledge and decision-making know-how. The reverse was true for CDA, where being uncomfortable was associated with more career exploration and planning. This dissociation of results for CDA and CDK is a strong argument for examining career maturity in its component parts, rather than treating it as a unitary construct, as is often the case in the literature (e.g., Naidoo et al, 1998). Lastly, career decision-making selfefficacy did not emerge as an individual predictor of the knowledge based CDK variable, even though it was the strongest predictor of career exploration and planning. While this career 
confidence variable is associated with career-related activities, it is not associated with how much career- related material is acquired. This finding further supports the separate examination of these two dimensions in career maturity research.

Contrary to other findings (Luzzo, 1993; Tan, 1989), school achievement was not a strong predictor of career development attitude or knowledge. One explanation of this may be because of the self-report variable used, but it may also reflect changes occurring in schools where there is an increased focus on catering for the career concerns of low achieving students (e.g., with the introduction of school-based apprenticeships) as well as high achievers (e.g., via the traditional focus on preparation for tertiary education). Socioeconomic status also did not emerge as a strong predictor in the current study. Other studies have reported minor associations between this variable and career maturity in school aged adolescents (Crites, 1978; Super \& Nevill, 1984), although the results in the present study may reflect a restriction of range, with all students coming from the same school and being drawn from a similar SES catchment area. Future studies may test this by examining students across wider SES categories.

\section{Conclusion}

While limited by a sample of one school, and data gained from self-report measures, including self-report of school achievement, the present study has identified important predictors of career maturity. In particular, it has shown that these predictors are different for career maturity attitude and career maturity knowledge. Further, as the amounts of variance identified for CDA and CDK varied, it is clear that there are still gaps in our understanding of the correlates of career maturity knowledge as compared with the attitude dimension. The study has also confirmed the applicability of aspects of Super's theory to Australian students. Hypothesized correlations among the career related variables support their relationships with each other and with career maturity. Further research should explore those variables that accounted for the most variance for each of career maturity attitude and career maturity knowledge for different gender and age 
groups in order to identify relevant determinants at each age level and for females and males separately. 


\section{References}

Achebe, C. C. (1982). Assessing the vocational maturity of students in the East Central State of Nigeria. Journal of Vocational Behavior, 20, 153-161.

Alvi, S. A., \& Khan, S. B. (1983). An investigation into the construct validity of Crites' career maturity model. Journal of Vocational Behavior, 22, 174-181.

Anderson, D. S., \& Vervoorn, A. E. (1983). Access to privilege: Patterns of participation in Australian post-secondary education. Canberra, Australia: Australian National University Press.

Betz, N. E., Klein, K. L., \& Taylor, K. M. (1996a). Career Decision-making Self-Efficacy: Short Form. Columbus, OH: Ohio State University, Department of Psychology.

Betz, N. E., Klein, K. L., \& Taylor, K. M. (1996b). Evaluation of a short form of the Career Decision-making Self-Efficacy Scale. Journal of Career Assessment, 4, 47-57.

Bloor, D., \& Brook, J. (1993). Career development of students pursuing higher education. New Zealand Journal of Educational Studies, 28(1), 57-68.

Brusoki, G. C., Golin, A. K., Gallagher, R. P., \& Moore, M. (1993). Career group effects on career indecision, career maturity, and locus of control of undergraduate clients. Journal of Career Assessment, 1, 309-320.

Creed, P. A., \& Patton, W. (in press). The relationship between career maturity and work commitment in a sample of Australian high school students. Journal of Career Development.

Creed, P. A., \& Patton, W. (2001). The effect of paid work experience on the career maturity of high school students. Manuscript submitted for publication.

Crites, J. O. (1978). Theory and research handbook for the Career Maturity Inventory $\left(2^{\text {nd }}\right.$ Ed.). Monterey, CA: CTB/McGraw-Hill.

Crites, J. O., \& Savickas, M. L. (1995). Career Maturity Sourcebook: Source book. Clayton, NY: Careerware. 
Feather, N. T., \& Davenport, P. R. (1981). Unemployment and depressive affect: A motivational and attributional analysis. Journal of Personality and Social Psychology, 41, 422436.

Feather, N. T., \& O'Brien, G. E. (1986). A longitudinal analysis of the effects of different patterns of employment and unemployment on school-leavers. British Journal of Psychology, 77, 459-479.

Fouad, N. A. (1988). The construct of career maturity in the United States and Israel. Journal of Vocational Behavior, 32, 49-59.

Hartman, B., Fuqua, D., Blum, C., \& Hartman, P. (1985). A study of the predictive validity of the Career Decision Scale in identifying longitudinal patterns of career indecision. Journal of Vocational Behavior, 27, 202-209.

Hartman, B., Fuqua, D., \& Hartman, P. (1983). The construct validity of the Career Decision Scale administered to high school students. Vocational Guidance Quarterly, 31, 250-258.

Hartman, B., \& Hartman, P. (1982). The concurrent and predictive validity of the Career Decision Scale adapted for high school students. Journal of Vocational Behavior, 20, 244-252.

Kelly, K. R., \& Colangelo, N. (1990). Effects of academic ability and gender on career development. Journal for Education of the Gifted, 13, 168-175.

Lokan, J. (1977). Locus of control in relation to Super's theory of vocational maturity during adolescence. Unpublished doctoral dissertation, University of Ottawa.

Lokan, J. (1984). Manual of the Career Development Inventory- Australian Edition. Melbourne: ACER.

Lokan, J. J., \& Shears, M. J. (1995). Studies of work importance in Australia. In D. E. Super \& B. Sverko (Eds.), Life roles, values and careers: International findings of the Work Importance Study (pp. 77-99). San Francisco: Jossey-Bass.

Luzzo, D.A. (1993). Predicting the career maturity of undergraduates: A comparison of 
personal, educational, and psychological factors. Journal of College Student Development, 34, 271-275.

Luzzo, D.A. (1995). The relationship between career aspiration-current occupation congruence and the career maturity of undergraduates. Journal of Employment Counseling, 32, $132-140$.

Luzzo, D.A., McWhirter, E. H., \& Hutcheson, K.G. (1997). Evaluating career decisionmaking factors associated with employment among first-year college students. Journal of College Student Development, 38, 166-172.

Naidoo, A. V., Bowman, S. L., \& Gerstein, L. H. (1998). Demographics, causality, work salience, and the career maturity of African-American students: A causal model. Journal of Vocational Behavior, 53, 15-27.

Nevill, D. D., \& Super, D. E. (1988). Career maturity and commitment to work in university students. Journal of Vocational Behavior, 32, 139-151.

Niles, S., \& Herr, E. L. (1989). Using secondary school behaviors to predict career behaviors in young adulthood: Does "success" breed "success"? The Career Development Quarterly, 32, 345-355.

Osipow, S. H. (1987). Career Decision Scale manual. Odessa, FL: PAR.

Patton, W., \& Creed, P. A. (2001). Developmental issues in career maturity and career decision status. The Career Development Quarterly, 49, 336-351.

Patton, W., \& Lokan, J. (2001). Perspectives on Donald Super's construct of career maturity. International Journal of Educational and Vocational Guidance, 1, 31-48.

Powell, D. F., \& Luzzo, D. A. (1998). Evaluating factors associated with the career maturity of high school students. The Career Development Quarterly, 47, 145-149. 
Prideaux, L., \& Creed, P. A. (2001). Career maturity, career decision-making self-efficacy, and career indecision: A review of the accrued evidence. Australian Journal of Career Development, 10, 7-12.

Rojewski, J. W. (1994). Career indecision types for rural adolescents from disadvantaged and nondisadvantaged backgrounds. Journal of Counseling Psychology, 41, 356-363.

Rojewski, J. W., Wicklein, R. C., \& Schell, J. W. (1995). Effects of gender and academic risk behaviour on the career maturity of rural youth. Journal of Research in Rural Education, 11, 92104.

Rosenberg, M. (1965). Society and the adolescent self-image. Princeton, N.J.: Princeton University Press.

Rowley, K., \& Feather, N. (1987). The impact of unemployment in relation to age and length of unemployment. Journal of Occupational Psychology, 60, 323-332.

Savickas, M. (1999). The transition from school to work: A developmental perspective. The Career Development Quarterly, 4, 326-336.

Sheridan, B. (1981). Career development in adolescents: Its relationship to orientation to work and locus of control. Unpublished doctoral dissertation, University of Western Australia.

Stead, G. B., \& Watson, M. B. (1998). The appropriateness of Super's career theory among Black South Africans. South African Journal of Psychology, 28, 40-43.

Super, D. (1957). The psychology of careers. New York: Harper.

Super, D. (1990). A life span, life-space approach to career development. In D. Brown \& L. Brooks (Eds.), Career choice and development (2nd ed., pp. 197-261). San Francisco, CA: Jossey-Bass.

Super, D. E., \& Nevill, D. D. (1984). Work role salience as a determinant of career maturity in high school students. Journal of Vocational Behavior, 25, 30-44. 
Tabachnik, B. G., \& Fidell, L. S. (1996). Using multivariate statistics. New York: HarperCollins.

Tan, E. (1989). The career maturity of Singaporean adolescents—-where do we stand and what can be done? Singapore Journal of Education, 10(2), 40-50.

Taylor, K. M., \& Betz, N. E. (1983). Applications of self-efficacy theory to the understanding and treatment of career indecision. Journal of Vocational Behavior, 22, 63-81.

Watson, M. B. (1984). Career development of coloured high school pupils. Unpublished doctoral dissertation, University of Port Elizabeth, Port Elizabeth.

Watson, M. B., Stead, G. B., \& De Jager, A. C. (1995). The career development of black and white South African university students. International Journal for the Advancement of Counselling, 18, 39-47.

Watson, M. B., \& Van Aarde, J. A. (1986). Attitudinal career maturity of South African colored high school pupils. Journal of Vocational Behavior, 29, 7-16.

Winefield, A. H., Tiggemann, M., Winefield, H. R., \& Goldney, R. D. (1993). Growing up with unemployment. London: Routledge. 